\title{
PHYTOCHEMICAL SCREENING AND EVALUATION OF ANTIMICROBIAL ACTIVITY OF Albizia ferruginea (FABACEAE) LEAVES EXTRACT
}

*Yusuf, A. L., Abdullahi, B. and Abdulaziz, I.

Department of Chemistry Federal College of education, zaria, kaduna state. * Corresponding Author's email: aishayusuflawal@gmail.com

\section{ABSTRACT}

Phytochemical and antimicrobial activity of methanol extract of Albizia ferruginea (Guill and Perr) which belongs to the family of Fabaceae were studied. Phytochemical studies on the plant leaves showed that they contained alkaloids, tannins, flavonoids, steroids, saponins, cardiac glycoside and carbohydrate. Methanol extract of Albizia ferruginea showed growth inhibitory effects of varying degrees on S. feacalis, S. typhi, S. paratyphi, Shigella dysentriae and Klebsiella pneumonia but was not active on Streptococcus pyogenes and Pseudomonas aeruginosa. The minimum inhibitory concentration (MIC) of the extract was determined for the organisms whose growths were inhibited. The extract had MIC of $3.25 \mathrm{mg} / \mathrm{ml}$ for S. feacalis, S. paratyphi, S. dysentriae and $\mathrm{K}$. pneumoniae respectively. The antimicrobial studies of the extracts really justify the numerous folkloric uses of the plant parts in the treatment of some common ailments such as diarrhea, dysentery, fever, cough, pain and skin infections.

Keywords: Antimicrobial activity, Albizia ferruginea, Minimum Inhibitory Concentration

\section{INTRODUCTION}

The search for medicines, which undoubtedly began in prehistorical times, has led to compounds such as morphine, atropine, tubocurarine, quinine and digoxin (Bogers et al., 2006), as such, plants and animals have provided substances used for their biological activity, to heal or to kill, and form the foundation for folk medicine (Bogers et al., 2006).

The medicinal value of plants has assumed a more important dimension in the past few decades owing largely to the discovery that extracts from plants contain not only minerals and primary metabolites but also a diverse array of secondary metabolites with medicinal potential (Modak et al., 2007; Farrukh et al., 2006). However, the use of plants as medicines by the local people may account for $70 \%$ or more of the basic healthcare treatment in Africa (World Conservation Monitoring Centre, 1992). It was also estimated that two-third of the world's population rely on plant-derived drugs with some 7000 medicinal compounds used in western pharmacopoeia derived from plants (Cho et al., 2003).

Antimicrobial agents are essentially important in reducing the globalburden of infectious diseases (Bhatai\& Narain 2010). However, emergence and dissemination of multidrug resistant (MDR) strain in pathogenic bacteria have become a significant public health threat as there are fewer, or even sometimes no, effective antimicrobial agents available for the infection caused by pathogenic bacteria (Sarita et al., 2019).Plant based antimicrobial have enormous therapeutic potentials and have provided a good source of anti-infective agents which are highly potent instruments in the fight against infection. Phytomedicines derived from plants have also shown great promise in the treatment of intractable infectious diseases including opportunistic AIDS infections (Iwu et al., 1999). Ashbolt (2004) observed that, infectious diseases have threatened the life of millions of people around the world during the last decade. Haque et al. (2003)estimated that one in every five children die before attaining fifth year almost due to diarrhea in developing countries. Thus the search for medicinal agents in plants may pave a new dimension and promising indication of drug potency of plants against pathological conditions, such as Cardiovascular, Arthritis, Cancer and Alzheimer's diseases.

The plant Albizia ferruginea is a tree that grows up to $15-30 \mathrm{~m}$ (sometimes to $45 \mathrm{~m}$ ) high, with unbuttressed bole clear to $20 \mathrm{~m}$ or more in diameter; with spreading branches to a flattened crown, of the deciduous and dry forest from Senegal to Nigeria, and extending across central Africa to Uganda and Angola. Different communities have different names for the plant.Igbo: igu, Yoruba: Ayinre, Hausa: Tsintsiyar Kurmii (Burkill, 1995). Akan-Asante 
BAJOPAS Volume 14 Number 1, June, 2021 (Ghana): awiemfo-samina, Balanta (The Wood Explorer, 2009). The root bark was reported to contain saponins, triglycerides and also triterpenoids and is taken in Cote d'Ivoire and Senegal for dysentry and to wash sores. A decoction is used in Senegal for bronchial infections, asthma and fever pains. Root bark is powdered and taken with salt in Nigeria for constipation. In Sierra Leone, leaves are being boiled and inhaled for headaches, fevers etc. The root bark is used in Cote d'Ivoire for gonorrhea, burns and convulsions in infants; it is considered to be analgesic and a good remedy for intestinal pain, to be haemostatic, antiseptic, vulnerary and laxative (Burkill, 1995)

Plants of the Fabaceae are well-recognised source of secondary metabolites. They have been studied from various points of view for the chemical components such as alkaloids, saponins, glycosides, flavonoids and terpenes. They represents the family of plants of tremendous interest in the search for active plant constituents against infectious diseases, through in vitroand in vivo antimicrobial evaluations. Plants of the Fabaceae have demonstrated significant antimicrobial potentials. For instance, Albiziainundata was reported for effective anticandida activity from Brazilian flora. Lipophilic extracts of Albiziagummi-fera revealed very promising antitrypanosomal activity (Freiburghaus et al., 2007;Agyare et al., 2006). Sutherlandia frutescens was reported to have antibacterial activity (David \& Jacobus, 2005). The extracts of leaf, root, stem and the callus obtained from Pseudarthria viscida(L.) Wight \& Arn., showed significant inhibitory activity against some fungal pathogens causing major diseases. Ethanol extracts of Acaciamangium Wild and Acacia auriculiformis A. Cunn., revealed significant antifungal activity when the growth of wood rotting fungi in in vitro assays was observed in crop plants and stored food grains (Rie et al., 2005).

As the focus of medicine shifts from treatment of manifest disease to prevention, increasing awareness on herbal remedies as potential sources of medicines have grown in recent years, and several plants are being screened for their antimicrobial properties using different assays (Sabrina et al., 2019). This work was designed to investigate the phytochemical and antimicrobial activity of methanol leaves extract of Albizia ferruginea with a view to assessing the potentials of the plant as a source for phytomedicine.

\section{MATERIALS AND METHODS}

\section{Sample Collection and Preparation}

Albizia ferruginea plant sample was collected along theBasawa barracks Road, Zaria, Kaduna State. It was confirmed and authenticated by the curator of Herbarium at the Department of Biological Sciences, Ahmadu Bello University, Zaria, a voucher Specimen Number 2033 was deposited. The sample was air dried in the laboratory at room temperature and grounded to powder using pestle and mortar.

\section{Extraction of Plant material}

Albizia ferruginea leaves $(500 \mathrm{~g})$ was subjected to cold extraction (percolation) for two weeks in methanol. The percolated sample was then filtered using Whatman filter paper No. 2 on a Buchner funnel. The residue was then percolated for another two weeks, concentrated using rotary evaporator at $45^{\circ} \mathrm{C}$ and placed in pre-weighed container before drying (Aliyu et al., 2008).

\section{Phytochemical screening}

The crude extract was subjected to phytochemical screening using standard techniques reported by Harborne (1998), Sofowora (1982) Trease \& Evans (2002) to identify the secondary metabolites; alkaloids (Mayer's and Draggendorff's test), flavonoids (Shinoda test), terpenoids (Salkowski test), tannins (Ferric chloride test), saponins (Frothing test), cardiac glycosides (Keller-Killiani test) and anthraquinones (Borntrager's test).

\section{Antibacterial screening}

The antibacterial screening of extract from Albizia ferruginea plant was determined using some pathogenic microorganism, the microorganisms were obtained from the Department of Medical Microbiology, Ahmadu Bello University, Teaching Hospital Zaria. All the isolates were used as pure cultures and maintained in slants of nutrient agar. Agarwell diffusion method was used to investigate the antibacterial activities of the extracts from the plant. $0.3 \mathrm{~g}$ of the extract were weighed and each was dissolved in $10 \mathrm{ml}$ of DMSO to obtain a concentration of $30 \mathrm{mg} / \mathrm{ml}$. This was the initial concentration of the extracts used to check the antibacterial activity of the plant against the test microorganism.

Mueller Hinton agar was the method used as the growth media and was prepared according to the manufacturer's instructions, boiled to dissolve once was sterilized at $121^{\circ} \mathrm{C}$ for 15 mins. The media was allowed to cool to $45^{\circ} \mathrm{C}$ and 20 $\mathrm{ml}$ of the sterilized media was then poured into sterile petri dishes, the plates were allowed to cool and solidify, the media were then seeded with $0.1 \mathrm{ml}$ of the test microorganism, the inoculums was spread evenly over the surface of 
BAJOPAS Volume 14 Number 1, June, 2021 the media by the use of sterile swab, the plates were allowed to dry at $37^{\circ} \mathrm{C}$ for $30 \mathrm{~min}$. Mueller Hinton agar was the method used as the growth media and was prepared according to the manufacturer's instructions, boiled to dissolve once was sterilized at $121^{\circ} \mathrm{C}$ for $15 \mathrm{mins}$. The media was allowed to cool to $45^{\circ} \mathrm{C}$ and $20 \mathrm{ml}$ of the sterilized media was then poured into sterile petri dishes, the plates were allowed to cool and solidify, the media were then seeded with $0.1 \mathrm{ml}$ of the test microorganism, the inoculums was spread evenly over the surface of the media by the use of sterile swab, the plates were allowed to dry at $37^{\circ} \mathrm{C}$ for $30 \mathrm{~min}$.

A standard cork borer of $6 \mathrm{~mm}$ in diameters was used to cut a well at the centre of each inoculated plate and $0.1 \mathrm{ml}$ of the solution of the extract was then introduced into each well on the media, the plates were incubated at $37^{\circ} \mathrm{C}$ for $24 \mathrm{hrs}$ after which the plates were observed for zone of inhibition of growth, the zones were measured with a transparent ruler and the result resolved in millimeters (Perez et. al., 1990).

Determination of minimum inhibitory concentration

Minimum inhibition concentration of the extract was carried out using broth dilution. Nutrient broth was weighed according to the manufacturer's instruction, $10 \mathrm{ml}$ of the broth was dispensed into test tubes, sterilized at $121^{\circ} \mathrm{C}$ for $15 \mathrm{~min}$ and the broth allowed to cool. McFarland's turbidity standard scale number 0.5 was prepared to give a turbid solution, normal saline was prepared and $10 \mathrm{ml}$ of the saline was dispensed into test-tubes and the test microorganism were then inoculated into different test-tubes containing the normal saline. Incubation of the saline was made at $37^{\circ} \mathrm{C}$ for 6 hrs, dilution of the test microorganism in the

RESULTS AND DISCUSSION

Table 1: Phytochemical screening of leave extract of $A$. ferruginea

\begin{tabular}{ll}
\hline Phytochemicals & Results \\
\hline Alkaloids & + \\
Flavonoids & + \\
Saponins & + \\
Tannins & + \\
Triterpenes & + \\
Anthraquinones & - \\
Cardiac glycosides & - \\
\hline
\end{tabular}

Key: $+=$ present,$-=$ absent

The screening of methanol extract of Albizia ferruginea revealed the presence of alkaloids, flavonoids, tannins, saponins and triterpenes. Anthraquinones and Cardiac glycosides were absent in the extract as shown in table 1 .

These metabolites have been reported to have medicinal properties (Ajay and Neetu, 2011). normal saline was done continuously until the turbidity marched that of the Mcfarland's scale by visual comparison. At this point, the microorganism has a concentration of about 1.5 x $10^{8} \mathrm{cfu} / \mathrm{m}$.

Two-fold serial dilution of the extract in the broth was performed to obtain concentrations of $30 \mathrm{mg} / \mathrm{ml}, 15 \mathrm{mg} / \mathrm{ml}, 7.5 \mathrm{mg} / \mathrm{ml}, 3.2 \mathrm{mg} / \mathrm{ml}$, $1.625 \mathrm{mg} / \mathrm{ml}$ and $0.8125 \mathrm{mg} / \mathrm{ml}$. The initial concentration was obtained by dissolving $0.3 \mathrm{~g}$ of the extract in $10 \mathrm{ml}$ of the sterilized broth. Having obtained the different concentrations of the extract in the broth, $0.1 \mathrm{ml}$ of the standard inoculums of the test microorganism in the normal saline was then inoculated into the different concentration of the extract in the broth, the broth was then incubated at $37^{\circ} \mathrm{C}$ for 24 hrs after which the broth was observed for turbidity (growth). The lowest concentration of the extract in the broth which showed no turbidity represented the minimum inhibitory concentration (MIC)( Usman et. al., 2013).

\section{Determination of minimum bactericidal} concentration

Minimum Bactericidal Concentrations of the extract was also carried out to check whether the test microorganisms were killed or only their growth was inhibited. Mueller Hinton agar was prepared, boiled and was sterilized at $121^{\circ} \mathrm{C}$ for $15 \mathrm{~min}$, cooled and $20 \mathrm{ml}$ was poured into sterile petri dishes, covered and allowed to cool and solidify. The contents of the MIC in the serial dilution were then sub-cultured onto the prepared medium, the medium were incubated at $37^{\circ} \mathrm{C}$ for $24 \mathrm{hrs}$, after which the plates were observed for colony growth, the MBC was the plate with lowest concentration of the extract without growth (Usman et. al., 2013).
Flavonoids have aroused considerable interest recently because of their potential beneficial effects on human health. They have been reported to have antiviral, anti-allergic, antiplatelet, anti-inflammatory, antitumor and antioxidant activities ( Sofowora, 1982). 
BAJOPAS Volume 14 Number 1, June, 2021

Table 2 : Antibacterial screening and zones of inhibition of methanol extract

\begin{tabular}{lll}
\hline Test Organism & Antibacterial Screening & Zones of Inhibition \\
\hline Streptococcus pyogenes & $\mathrm{R}$ & 0 \\
Streptococcus feacalis & $\mathrm{S}$ & 28 \\
Salmonella typhi & $\mathrm{S}$ & 25 \\
Salmonella paratyphi & $\mathrm{S}$ & 27 \\
Shigella dysentriae & $\mathrm{S}$ & 28 \\
Klebsiella pneumoniae & $\mathrm{S}$ & 25 \\
Pseudomonas aeruginosa & $\mathrm{R}$ & 0 \\
\hline
\end{tabular}

Key: $\mathrm{R}=$ Resistance, $\mathrm{S}=$ Sensitive

The results showed that the test organisms Streptococcus feacalis, Salmonella typhi, Salmonella paratyphi, Shigella dysentriae and Klebsiella pneumonia growth were inhibited by them ethanol extract of Albiziaferruginea. However, the gram-positive bacteria Streptococcus pyogenes and the gram-negative bacteria Pseudomonas aeruginosa were resistant to the extract. The extract showed significant zones of inhibition between20-30 (mm)against the selectedgram-positive and gram-negative bacteria (Table 2 ). The results were remarkable, indicating the antibacterial potentials of the extract against clinical human pathogens.

Table 3: Minimum Inhibitory concentration (MIC) of methanol extract of Albizia ferruginea leaves

\begin{tabular}{|c|c|c|c|c|c|c|}
\hline Test Organism & $30 \mathrm{mg} / \mathrm{ml}$ & $15 \mathrm{mg} / \mathrm{ml}$ & $7.5 \mathrm{mg} / \mathrm{ml}$ & $3.25 \mathrm{mg} / \mathrm{ml}$ & $1.625 \mathrm{mg} / \mathrm{ml}$ & $0.8125 \mathrm{mg} / \mathrm{ml}$ \\
\hline $\begin{array}{l}\text { Streptococcus } \\
\text { pyogenes }\end{array}$ & - & - & - & - & - & - \\
\hline $\begin{array}{l}\text { Streptococcus } \\
\text { feacalis }\end{array}$ & - & - & - & $0+$ & + & ++ \\
\hline Salmonella typhi & - & - & - & $0+$ & + & ++ \\
\hline Salmonella paratyphi & - & - & - & $0+$ & + & ++ \\
\hline Shigella dysentriae & - & - & - & $0+$ & + & ++ \\
\hline $\begin{array}{l}\text { Klebsiella } \\
\text { pneumonia }\end{array}$ & - & - & - & $0+$ & + & ++ \\
\hline $\begin{array}{l}\text { Pseudomonas } \\
\text { aeruginosa }\end{array}$ & - & - & - & - & - & - \\
\hline
\end{tabular}

Table 4: Minimum Bactericidal Concentration (MBC) of methanol fraction of Albizia ferruginea leaves

\begin{tabular}{|c|c|c|c|c|c|c|}
\hline Test Organism & $30 \mathrm{mg} / \mathrm{ml}$ & $15 \mathrm{mg} / \mathrm{ml}$ & $7.5 \mathrm{mg} / \mathrm{ml}$ & $3.25 \mathrm{mg} / \mathrm{ml}$ & $1.625 \mathrm{mg} / \mathrm{ml}$ & $0.8125 \mathrm{mg} / \mathrm{ml}$ \\
\hline $\begin{array}{l}\text { Streptococcus } \\
\text { pyogenes }\end{array}$ & - & - & - & - & - & - \\
\hline $\begin{array}{l}\text { Streptococcus } \\
\text { feacalis }\end{array}$ & - & $0+$ & + & ++ & +++ & ++++ \\
\hline Salmonella typhi & $0+$ & + & ++ & +++ & ++++ & +++++ \\
\hline Salmonella paratyphi & $0+$ & + & ++ & +++ & ++++ & +++++ \\
\hline Shigella dysentriae & - & $0+$ & + & ++ & +++ & ++++ \\
\hline $\begin{array}{l}\text { Klebsiella } \\
\text { pneumoniae }\end{array}$ & $0+$ & + & ++ & +++ & ++++ & +++++ \\
\hline $\begin{array}{l}\text { Pseudomonas } \\
\text { aeruginosa }\end{array}$ & - & - & - & - & - & - \\
\hline
\end{tabular}

The extract exhibited growth inhibition with MIC value of $3.25 \mathrm{mg} / \mathrm{ml}$ against the tested microorganisms with the exception of $S$. pyogenes and $P$. aeruginosa, while the MBC was observed at $15 \mathrm{mg} / \mathrm{ml}$ against $S$. feacalis and $S$. dysentriae and at $30 \mathrm{mg} / \mathrm{ml}$ for $S$. typhi, S. paratyphi and $K$. pneumonia.

Formatted: Font: (Default) Tahoma, 10 pt, Not Italic, Font color: Text 1 
BAJOPAS Volume 14 Number 1, June, 2021 The results from the antimicrobial analysis revealed that, the extracts of Albizia ferruginea have significant antibacterial activity and thus could be used as effective antimicrobial agents. This is in line with findings froma study on methanol extract of Albizia gummifera by Unasho et al (2003) which revealed its potential as an antimicrobial agent, whereas Antimicrobial studies by Sabrina et al. (2005) on ethyl acetate extract of Albizia grandibracteata revealed its use as a potential antiinfective agent.

Despite the tremendous progress in human medicines, infectious diseases are still a major threat to public health. Their impact is intense in the developing countries particularly due to relative unavailability of the medicines and the emergence of drug resistance (Okeke et al., 2005). In case of immuno compromised AIDS and cancer patients, drug resistant bacteria, virus and fungal pathogens have further complicated the treatment of infectious diseases (Diamond, 1993). Thus, in the present scenario of multiple drug resistance to infectious pathogens, it is important that the search for new antimicrobial substance from alternative sources including plants be initiated (Ahmed \& Beg,2001). Contrary to synthetic drugs, antimicrobials from plants are safe and possess effective therapeutic potential to treat several infectious diseases (Iwu et al., 1999). In an earlier study (Kaur \& Arora, 2008), both aqueous and methanol extract of different plants belonging to Umbelliferae shown marked antibacterial activity. However, in the present study, aqueous extract was not very much effective. Such differences could be attributed to the plant material, strain differences and

\section{REFERENCES}

Agyare, C., Koffuor, G. A., Mensah, A.Y. \&Agyemang, D.O. (2006). Buletin Latinoamericanoydel caribe de plants Medicinales .Y. Aromaticas, 5(2): 31-35

Ahmed, I. \&Beg, A.Z. (2001). Antimicrobial and phytochemical studies on 45 Indian medicinal plants against multidrug resistant human pathogens. J. Ethnopharmacol., 74: 113-123.

Ajay, K.S. \& Neetu, D. (2011). An overview: On Phytochemical and Pharmacological studies of Butea minosperma. Journal of Pharm Tech Research, 3(2): Pp 864871.

Aliyu, A. B.,Musa, A.M., Abdullahi, M. S. \& Oyewale, A. O. (2008). Phytochemical and antibacterial properties of Ludwigia suffruticosa (Willd). International protocols used. Furthermore, Richard et al. (2010) reported significant antibacterial and antifungal activities of methanol leave extract of E. abysinnica (Fabaceae) against some mycobacteria strains, which might be attributed to the plant family, containing pharmacologically active substances. In this study, the demonstration of the extracts activity against gram positive and gram negative bacteria is an indication of broad spectrum of activity and thus can be used to source antibiotic substances for drug development that can be used in the control of these bacterial infections.

\section{CONCLUSION}

Albizia ferruginea (Guill \& Perr) is an extremely valuable plant with both economic and potential therapeutic values. The plant has diverse ethno medical uses in Africa and the world at large. Albizia ferruginea leaves was extracted exhaustively. Preliminary phytochemical analysis conducted reveals the presence of some natural products such as alkaloids, tannins, flavonoids, steroids, saponins and cardiac glycoside.

Antimicrobial screenings of the extract was carried out in vitro on some clinical pathogens. The extract from the leaves was active on Streptococcus feacalis, Salmonella typhi, Salmonella paratyphi, Shigella dysentrea and Klebsiella pneumoniae but not active on Streptococcus pyogenes and Pseudomonas aureginosa. The spectrum of activity of the extracts could be said to be broad and this justifies the diverse use of the plant in folk medicine in the treatment of ailments such as diarrhea, dysentery, fever, cough, pain and skin infections.

Journal of Pure and Applied Sciences, 2 (4): $1-5$

Ashbolt, J. N. (2004). Microbial Contamination of Drinking Water and Disease outcomes in Developing Regions. Toxicology, 198:229-238

Bhatia, R. \& Narain,J.P.(2010)."The growing challenge of antimicrobial resistance in the South-East Asia Region - are we losing the battle?" Indian Journal of Medical Research, 132 (5): 482-486.

Bogers, R.J., Craker, L.E. \&Lange, D. (2006). Medicinal and Aromatic Plants. Springer, Printed in the Netherlands, 261-273.

Burkill, H. M. (1995) the useful plants of West Tropical Africa vol. 3 Families. JournalL, Royal Botanical Gardens, Kew. 210 211.

Cho, E. J., Yokozawa, T., Rhyu, D.Y., Kim, S.C., Shibahara, N. \& park, J.C. (2003) study on the inhibitory effects of korcan 
BAJOPAS Volume 14 Number 1, June, 2021 medicinal plants and their main compounds on the I,I-diphenyl-22picrylhdrazyl radical. Phytomedicine, 10: 544-551.

David, R. K. \& Jacobus, N. E. (2005).Antibacterial and antioxidant activity of Suthrelandia frutescens (Fabaceae), a reputed AntiHIV/AIDS. Phytotherapy Research, 19 (8): 779-781.

Diamond R.D. (1993). The growing problem by mycoses in patients infested with human immunodeficiency virus. Rev. Infect. Dis., 13:480-486

Farrukh, A., Iqbal, A. \&Zafar M. (2006). Antioxidant and Free Radical Scavenging Properties of Twelve Traditinally Used Indian Medicinal Plants. Turkish Journal of Biology, 30: 177183.

Freiburghaus, F., Ogwal, E.N. Nkunya, M.H., Kaminsky, R. \&Brun, R. (2007).In vitro antitrypanosomal activity of African plants used in traditional medicine in Uganda to treat sleeping sickness. Tropical Medicine and International Health, 1(6): 765-771.

Haque, R. Mondal, D. Kirkpatrick, B.D. Akthers, S. Fair, B.M, Sack, R.B. \& Peter, W. Jr.(2003). Epidemiologic and Clinical characteristics of acute diarrhea with emphasis on entamoeba histolytica infections in preschool children in an urban slum of Dhaka, Bangladesh. American Journal of Tropical Medicine and Hygiene, 69 (4): 398-405.

Harborne, J. B., (1998). Phytochemical Methods: $A$ Guide to Mordern Techniques of Plants Analysis. $3^{\text {rd }}$ Edition, Chapman and Hall, London, ISBN: 0-412-57270-2, 302.

Hill, A. F. (1952): Economic Botany. A text books of useful plants and plant products, edition McGraw Hill Book company Inc. New York, 1-38.

Iwu, M. M., Duncan, A. R. \&Okunji, C.O (1999).New Antimicrobial of plant origin. In: Janick, J. (ed) Perpsectives on new cross and new uses. Ashs press, Alexandria, V.A. 457-462.

Junaid, S. A., Abubakar, A., Ofodile, A.C., Olabode, A. O., Echeonwu, G. O., Okwori, A. E. \& Adetunji, J. A. (2008). Evaluation of Securridaca longipenduculata leaf and root extracts for antimicrobial activities. Afr. J. Microbiol. Res., 2: 322-325.

Kaur, G. J. \&Arora, D. S. (2008).In vitro antibacterial activity of three plants belonging to the family Umbelliferae.Int. J. Antimicrobial Agents, 31: 393-395.

Modak, B., Torres, R. Lissi, E. \& Monade, F.D. (2003) Antioxidant Capacity of flavonoids and a new aryl phenol of the resinous exudates from Heliotropium
Sinuatum. Natural Product Research, 17(6): 403-407.

Okeke I.N., Laxmaninarayan R., Bhutta Z.A., Duse A.G., Jenkins P., O'Brien T.F., PablosMendez A.\&Klugman K.P.(2005). Antimicrobial resistance in developing countries. Part 1: Recent trends andcurrent status. Lancet Infect. Dis., 5: 481-593.

Perez, C., Paul, M. \& Bazerque, P. (1990).Antibiotic assay by agar well diffusion method.Acta Biol. Med.Exp.,15: 113-115.

Richard, M. M., John, A. O., Paul, O. O. \& Paul, K. M. (2010).Antifungal, Antibacterial and Antimycobacterial activity of Entada abysinnica Steudel ex A. Rich (Fabaceae) methanol extract. Pharm. Res., 2 (3) :163168.

Rie, M., Karen, M.B., Caroline, L.M. \& Tohru, M. (2005).Comparison of antifungal and antioxidant activities of A.mangiumandA. auriculiformis. Journal Chemical Ecology, 31(4).

Sabrina Krief, Odile Thoison, Therry sevenet, Richard .W. Wrangham \& Catherine Laraud (2005). Triterperiod saponin Anthranilates from Albizia grandlbracteata leaves ingested by primates in Uganda. Journal of Natural Product, 68(8): 897-903

Sarita, A., Shisir, L., \& Raj Kumar, D.(2019). In Vitro Antibacterial Activity of some Medicinal plants against Human Pathogenic Bacteria. Journal of Tropical Medicine 1895340.

Sofowora, E.A. (1982) Medicinal Plant and Traditional Medicine in Africa, $1^{\text {st }}$ EditionPublished by John Wiley and Sons, 6-160.

Trease, G.E. \& Evans, W.C. (2002) A Text Book of Pharmacognosy $13^{\text {th }}$ Edition, Bailliere Tindall Ltd. London, 134.

Unasho A., Geyid A., Melaku A., Debe L.A., Mekasha A. Girma S. Kebede T., Fantaw S. Asaminew N.\& Mamo K. (2009). Investigation of antibacterial activities of Albizia gummifera and Ferula communis on streptococcus pneumonia and streptococcus pyogenes.Ethiopia Medical Journal 47(1): 25-32.

Usman, A. K., Hazir, R. , Zeeshan, N., Muhammad, Q., Ja'afar, K., Tayyaba \& Bushra, R.( 2013). Antibacterial activity of some medicinal plants against selected human pathogenic bacteria. European J. Microbial Immunology 3: 272-274.

World conservation monitoring centre (1992). Global biodiversity status of the earth's living resources. Chapman \& hall London, England. 23-24. www.aaas.org/international/Africa/moz/ind 